\section{An Early Medieval Tradition of Building in Britain}

\section{La tradición constructiva de la alta Edad Media en Gran Bretaña}

Mark Gardiner*

Queen's University Belfast (United Kingdom)

\section{STUDYING TIMBER BUILDINGS}

Almost all domestic buildings in early medieval Britain were constructed of timber or earth sod. Hardly a single stone domestic building was constructed in the period between the fifth to the tenth century ${ }^{1}$. Indeed, masonry construction was not a well developed craft. Little quarrying took place and, if stone was required for the construction of churches, it had to be robbed from decaying Roman buildings, or in the case of upland Britain, gathered from the ground surface ${ }^{2}$. In areas of Scotland, particularly the Highlands where straight timbers were hard to obtain, earth sod was used instead of timber ${ }^{3}$. We cannot talk with any certainty about buildings of this period in Wales, because so few have been excavated. Wood was so important in most houses in England and southern Scotland that the Old English word timber served to refer to both the building and the material from which it was constructed.

That choice of building material poses immense problems for the study of early medieval domestic architecture. There are no standing timber buildings of this period: the earliest structure - the timber church at Greenstead - dates only to the end of the eleventh century ${ }^{4}$. The only surviving timbers from early medieval buildings are fragments of structures which have survived in water-logged conditions, particularly those found in York and London. The most common type of evidence for the presence of early medieval buildings are the holes dug into the ground to hold timber posts. On suitable soils, and with careful excavation, it may be possible not merely to record the holes dug for the posts, but to identify traces of decayed timbers, which are marked by darker coloured soil and known as 'post-ghosts'. The study of architecture of this period has been therefore a problem of interpreting how the timber buildings might have looked largely from the below-ground remains of the structure. Much ingenuity has been devoted to understanding the appearance of buildings above ground from these fragmentary traces.

The interpretation of early medieval buildings has drawn to varying degrees on four different approaches. The first of these might be described as retrogressive. It starts with the earliest surviving timber buildings and assumes that houses of an earlier date must have been built in a similar tradition, but perhaps in a slightly less sophisticated manner. There are seven standing domestic

\footnotetext{
${ }^{1}$ For a possible exception, see Smith 2012.

2 Parsons 1991, 6-17.

${ }^{3}$ Corser 1993.

${ }^{4}$ Tyers et al. 1997, 142, 150
} 


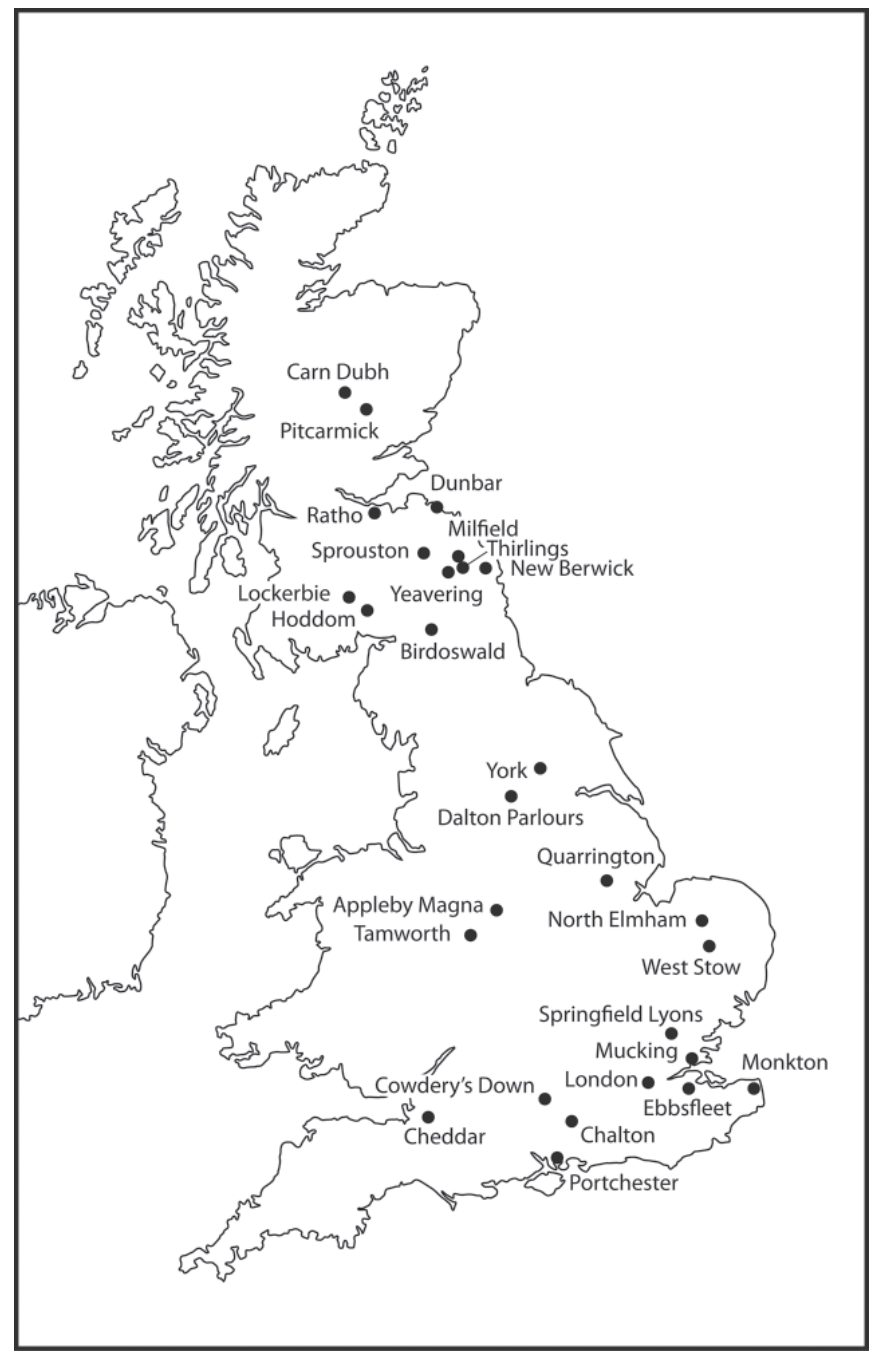

Fig. 1. Map of sites discussed in the text

buildings in England from before 1230. A study of these has allowed the common features of timber construction in the late twelfth and early thirteenth centuries to be identified $^{5}$. This has suggested, as earlier researchers had assumed, that the roofs of English buildings resembled those in northern France ${ }^{6}$. They had rafters of equal size (known as common-rafter roofs), often joined at the base by beams which ran across the building ${ }^{7}$. The key problem with the retrogressive approach is that it tells us the point or which timber construction reached in the twelfth century, but it really does not allow us to determine in what way earlier buildings might have been different. Its use in determining the character of buildings of the tenth century and earlier is therefore limited.

\footnotetext{
${ }^{5}$ Walker 1999.

${ }^{6}$ Smith 1958, 116-18.

${ }^{7}$ Currie 1983; Hoffsummer 2009, 261-64.
}

The application of the retrogressive approach is more problematic for Scottish buildings. The earliest standing vernacular buildings there belong to the seventeenth or eighteenth century. We cannot imagine what the early medieval buildings might have been like by looking at such distant descendants. It is unfortunate that this simple truth has not stopped some rather improbable interpretations. For example, the evidence of eighteenth-century vernacular buildings has been used in the very questionable interpretation of the seventh- to tenth-century site at Hoddom in south-west Scotland ${ }^{8}$. It is a common, but erroneous view that early buildings in both Scotland and England would have been constructed using cruck timbers. These are posts which ran from the ground up into the roof in a gentle curve (see Fig. 7). Such a method was once believed to be extremely 'primitive' and therefore was assumed to be typical of early medieval buildings. More recent work has shown that cruck construction is unlikely to have been used much before the thirteenth century?

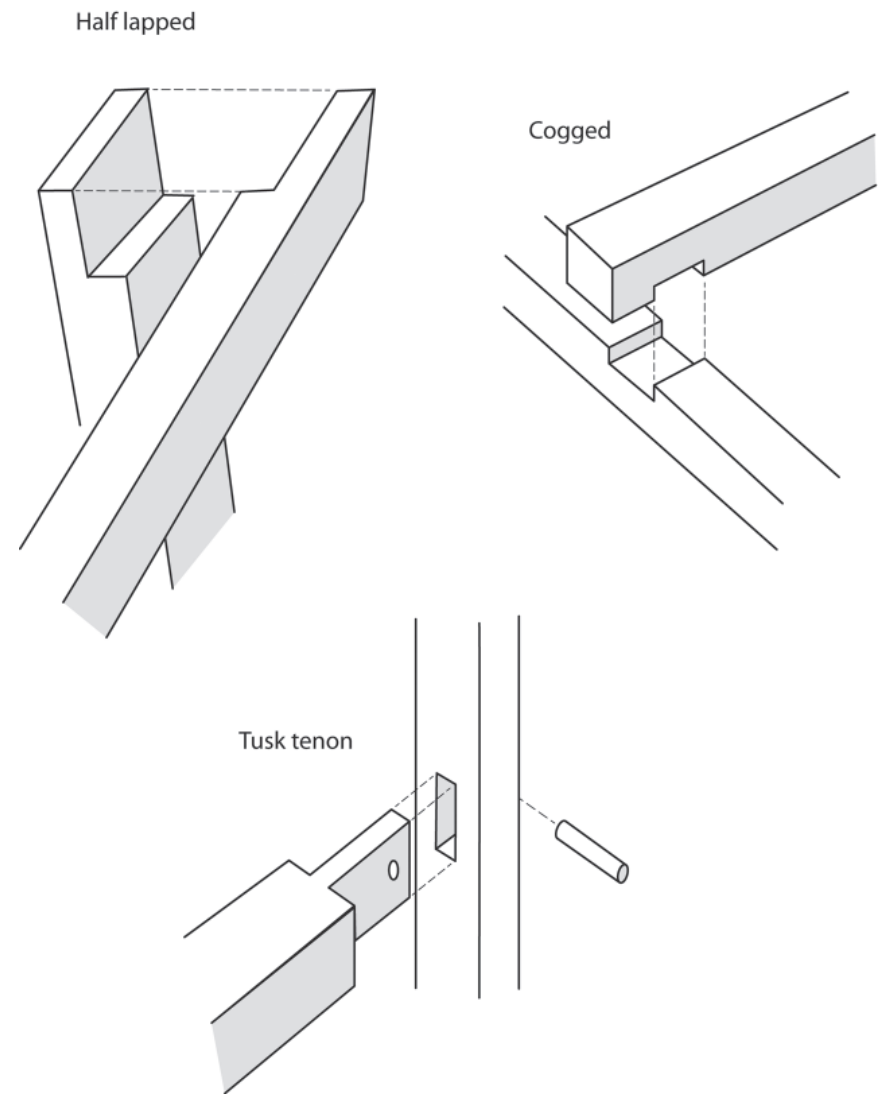

Fig. 2. Basic joints attested from excavated waterlogged timbers include lap, cogged and tusk tenons.

${ }^{8}$ Lowe 2006, 183-86.

${ }^{9}$ Addyman 1981; Meeson 2011, 75-76; Walton 1948. 
A
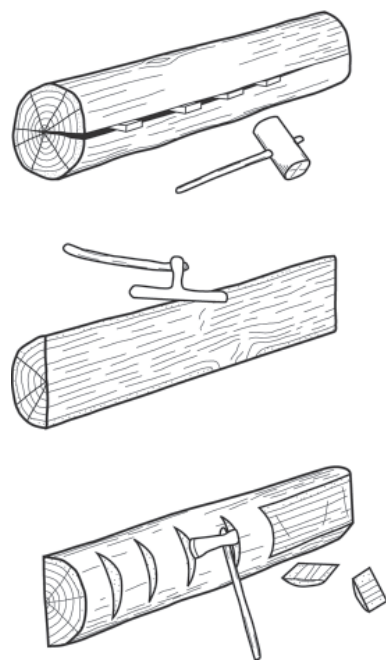

B
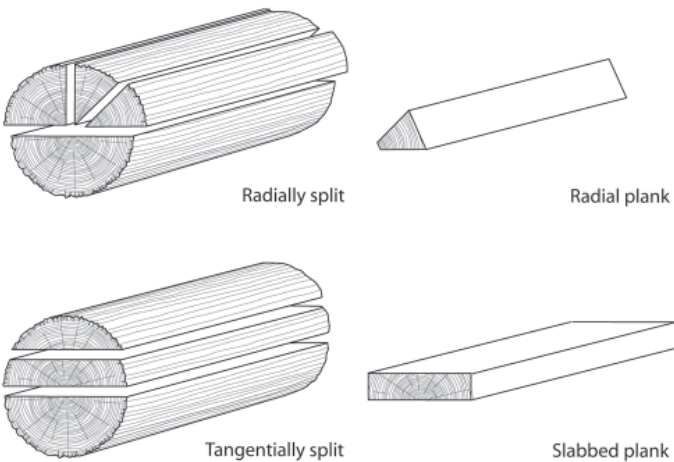

Fig. 3. A. Timber could be prepared in the early Middle Ages by splitting radially or tangentially. Once the timbers had been split to size, they were be finished by hewing (or trimming) the faces with a T-shaped axe and, where necessary, by removing the waste by notch-and-chop hewing (after Hill and Woodgar 1999, 49). B. Radial and tangetial planks.

It is inevitable that in the absence of standing buildings from before the second half of the twelfth century, archaeologists should turn to the study of those timbers which have been preserved in waterlogged conditions, even though they have survived in a fragmentary state. The number of sites with these conditions are very few because houses were rarely constructed in such wet locations. Timbers have been preserved in York where buildings were situated close to the River Ouse. That river was dammed in the later eleventh century to provide a moat for the castle, and consequently the water-level was raised upstream (Fig. $1)^{10}$. Similar conditions have also been found on harbour waterfronts in the city of London where house timbers were re-used ${ }^{11}$. The interpretation of these timbers has created some difficulties because it is not always clear from what part of the building they came. For instance, timbers in London originally identified as sole plates from the bottom of walls are now considered to be wall plates at the top $^{12}$. Early medieval watermills at Tamworth and at Ebbsfleet, while not providing evidence for house construction, have given further evidence of the types of joints used and the methods of working wood ${ }^{13}$. Cogged and lap joints, and tusk-tenons were used to join timbers, while vertical planks for walls were often set into grooves along

\footnotetext{
${ }^{10}$ Addyman 1979, 69-72; Addyman and Hall 1991; Hall and Hunter-Mann 2002, 681, 696 .

${ }^{11}$ Milne 1992.

${ }^{12}$ Goodburn 2007, 309.

${ }^{13}$ Hardy et al. 2011; Rahtz and Meeson 1992.
}

sole-plates, or set horizontally as weather-boarding pegged on to uprights (Fig. 2). The same techniques of woodworking are seen in two wells at North Elmham and Portchester, but it is somewhat different from the methods of assembly noted in the earliest standing timber buildings of the late twelfth century ${ }^{14}$. Goodburn has established that the methods of timber-working in the early medieval period were different both from those used in the preceding Roman era, and also from about 1180 onwards when new methods of jointing were adopted ${ }^{15}$. The saw was rarely used by woodworkers operating in the early medieval tradition. Most timbers (Fig. 3A, B) were prepared by cleaving (splitting the timber along its length using wedges) and hewing (cutting it smooth using a T-shaped axe) $)^{16}$.

One approach to methods of timber-working was to consider the tools used and to see whether the traces of toolmarks discovered on timbers from the early Middle Ages could be reproduced. The results of such experimental archaeology have only been published in part. The details of the toolmarks have been recorded and made available in summary form, but not the results of the work to reproduce them and confirm the methods of woodworking ${ }^{17}$. The ideal is clearly that the study of timberworking proceeds using the type of experimentation which

\footnotetext{
${ }^{14}$ Cunliffe 1976, 96-96; Wade-Martins 1980, 88-94.

${ }^{15}$ Goodburn 1991, 196-200; Goodburn 1992, 108-14, 126-29.

${ }^{16}$ Goodburn 2000, 194.

${ }^{17}$ Goodburn 1992, 112-12; Goodburn 2000, 188-94; Goodburn in Hardy et al. 2011, 337-46; Marsden 1989.
} 
Peter Reynolds described as 'simulation' - though 'reproduction' might be a more accurate way of explaining the processes - and the results published ${ }^{18}$.

A stage beyond the reproduction of methods of timber working is the reconstruction of entire buildings to investigate their structural strength, the technical problems involved in their erection and to consider their longevity. It is unfortunate that much important experimental work in this area also remains unpublished. For example, the reconstruction of buildings at Bede's World on Tyneside was intended to be a 'genuine attempt in academic experimentation', but few of the conclusions have been made available ${ }^{19}$. The long-term programme on the excavated site at West Stow is an exception to the generally poor dissemination of results. The interpretation of the archaeological evidence, the degree of repair and the decay of the buildings have all been published in full. Work there has also considered the question of the form of 'sunken buildings' (discussed further below), and has used the burning of a reconstructed house to examine how excavated evidence for such destroyed structures should be interpreted $^{20}$. While the work has not always been undertaken with the rigour of the experimental work at the famous Butser Hill experimental farm, it has been much more thorough than any other study and provides important data on the longevity of timbers and possible methods of construction used ${ }^{21}$.

Physical reconstruction is only one means of working out the form of buildings. The investigation on paper of the building methods is also a useful approach to thinking about building form. Paper interpretations allow archaeologists to think about the implications of their discoveries and experiment with alternative approaches, while not requiring the immense labour of constructing the houses. Almost as soon as large-scale excavation began to produce reasonable plans of houses, attempts were made to understand these in terms of three-dimensional structures. It is notable that one of the first efforts to do so, based on the work on the chalk downland at seventh-century site at Chalton (Hampshire), identified many of the features which more recent studies have confirmed. In a single key paragraph the authors noted four crucial features:

i) The posts appeared to be paired across the width

\footnotetext{
${ }^{18}$ Reynolds 1994, 10-12.

${ }^{19}$ Fowler 1999, 250; Grocock 2010; Mills 1999.

${ }^{20}$ Tipper 2004, 104-06; Tipper forthcoming; West 2001

${ }^{21}$ For the work at Butser Hill on Iron Ages buildings, see for example, Reynolds 1982 .
}

of the building implying that they supported some sort of truss (for example, see Fig. 6D).

ii) There was a lack of emphasis on the corner posts and the end walls were often very lightly built.

iii) The wall posts were so well aligned that there is every possibility that a wall-plate rested on top of these.

iv) There was no evidence for cruck framing 22 .

It will be argued below that these features are some of the key characteristics of what will be identified as an early medieval tradition of construction.

It is curious that the implications of these perceptive observations were not followed in the interpretations of the buildings appended to that paper. These showed the roof trusses unaligned with the posts, and the side wall construction similar to that in the end wall ${ }^{23}$. The interpretation of building structure has made disappointingly little progress in subsequent years, in spite of the carefully reasoned work by J. T. Smith on the buildings at Cheddar and at Yeavering ${ }^{24}$. The absence of any consensus about the character of early medieval buildings is reflected in the controversy often produced by attempted paper reconstructions. For example, the interpretation of the buildings at Cowdery's Down were criticized for incorporating anachronistic features of timber architecture ${ }^{25}$. In the same way, the interpretation of the tenth-century hall at Cheddar was considered by many to be more an exercise in imagination, than a strict interpretation of archaeological evidence ${ }^{26}$.

These four approaches to the interpretation of buildings - retrospective analysis, study of water-logged structures, reproduction of timber-working, and experimental reconstruction - have all contributed to a refined understanding of the form of early medieval structures. However, it is arguable that the most important stimulus to understanding buildings has been none of these. The careful consideration of the results of archaeological excavation on dryland sites continues to provide some of the most important, and certainly the most copious source of evidence, which has pushed forward knowledge of early medieval buildings, as recent papers on the subject demonstrate ${ }^{27}$. The comparative analysis of excavated buildings has begun to allow greater certainty in our understanding

\footnotetext{
${ }^{22}$ Addyman et al. 1972, 23.

${ }^{23}$ Addyman et al. 1972, 25-27.

${ }^{24}$ Cheddar in Rahtz 1979; Yeavering regrettably still unpublished.

${ }^{25}$ Millett and James 1983, 243-46; Alcock and Walsh 1993.

${ }^{26}$ Charles 1981, 19; Rahtz et al. 1982.

${ }_{27}$ Gardiner 2011; Hamerow 2011; Hamerow 2012, 17-66; Ulmschneider 2011.
} 
of early medieval buildings, and enabled work to move beyond simple questions about structure. It is now possible to consider the implications of the design for the spread of cultural influences and as a reflection of the ethnicity of the builders, the sophistication of construction, and the relationship between timber houses and stone churches. It is not possible to consider the work undertaken on all these issues here. ${ }^{28}$ Instead, it is appropriate to examine in greater depth the first of these issues, the spread of cultural influences, because it has played such an important part in the development of the study of early medieval domestic architecture.

\section{ETHNIC AFFINITIES}

The question of origins of building types or, more precisely, of ethnic affinities of early medieval house-builders has been an important consideration from an early stage in the study. In particular, it was hoped that it might throw some light on the extent of migration from north Germany to England in the fifth and sixth centuries. The interpretation of buildings has closely mirrored the wider arguments about Germanic migration. So, instead of adding a separate and independent strand of evidence to the debate, it has tended merely to reinforce the views already held about the extent of migration. In the 1980s, as doubts about the traditional story of large-scale migration from Angeln and Saxony to Britain were beginning to gain force, Philip Dixon challenged the view that post-built Anglo-Saxon houses (a term derived from the period of time, rather than the ethnicity of the occupants) were necessarily derived from continental origins ${ }^{29}$. The impression that these might in fact draw strongly from Romano-British origins gained further support with the appreciation that the buildings were often twice as long as they were wide - the 'double-square' plan - and that the same dimension were often used in British buildings of the third and fourth century $^{30}$. Furthermore, it was noted that there were significant differences between the aisled buildings of continental Europe and the total absence of aisles in Britain. The British buildings were less long and less wide than some of the continental examples (Wohnstalhäuser,) because they did not house livestock under the same roof as human inhabitants ${ }^{31}$. The continental origins of Gru-

\footnotetext{
${ }^{28}$ For studies on the sophistication of building techniques, see Dixon 2002 and Gardiner forthcoming a. For an examination of the relationship between timber houses and stone churches, see Rodwell 1986, 171-74 and Shapland forthcoming.

${ }^{29}$ Dixon 1982.

${ }^{30}$ James et al. 1984, 201-05.
}

benhäuser or sunken-featured buildings have also been queried. These were once held to be a certain marker of incoming Germanic settlers, but examples began to be excavated in Romano-British contexts ${ }^{32}$.

By the 1990s archaeologists were again returning to the idea that large-scale migrations might have occurred in prehistory and in the early historical period, and the Germanic roots of the early medieval house were again brought back into play ${ }^{33}$. Helena Hamerow while arguing that the 'ethnic origin of these buildings has proved inconclusive', was nevertheless prepared to venture that 'the closest parallels [lie] within the buildings traditions of the Migration Period in Continental Europe ${ }^{34}$. Yet the evidence was not quite as clear as that latter statement might suggest. While Hamerow was undoubtedly correct in arguing that the general plan of English fifth- and sixthcentury buildings was similar to those on the Continent, there was a wider question whether they were drawing upon a broader and perhaps vaguer cultural background common to a number of places bordering on the North Sea, as she indeed pointed out ${ }^{35}$. The work of both Hamerow and Zimmermann suggested that there was a general consensus on the ways in which domestic space should be organized in north-west Europe, but with local variations. The possibility of detecting distinctive cultural influences given this degree of uniformity seemed altogether more problematic.

The Grubenhäuser or sunken-featured buildings (SFBs) seemed to have a rather better claim to a continental pedigree than the post-built structures. The appearance of this type of buildings in the fifth century in Britain has long been connected with Germanic incomers since the type is widely found in continental Europe. However, the discovery of a small number of SFBs of Romano-British date which must pre-date the period of migrations raised some questions about this. More than twenty SFBs were found at Monkton in Thanet. Although some resembled early medieval buildings of this type, others were recognizably different ${ }^{36}$. Four examples were found at Appleby Magna at Leicestershire in central England and firmly dated to the second half of the fourth century. Other Roman examples are known from nearby at North Eving-

\footnotetext{
31 Zimmermann 1999, 134-35.

${ }^{32}$ E.g. Drury and Wickenden 1982, 33-34; Miles 1986, 16-18, 51-52. The term 'sunken-featured building was introduced by Rahtz (1976, 70-73).

${ }^{33}$ Chapman and Hamerow 1997; Härke 1998.

${ }^{34}$ Hamerow 1994, 170.

${ }_{35}$ Hamerow 1999, 122-25; Zimmermann 1988, 476-77; Zimmermann 1999,

134-35.

${ }^{36}$ Bennett et al. 2008.
} 


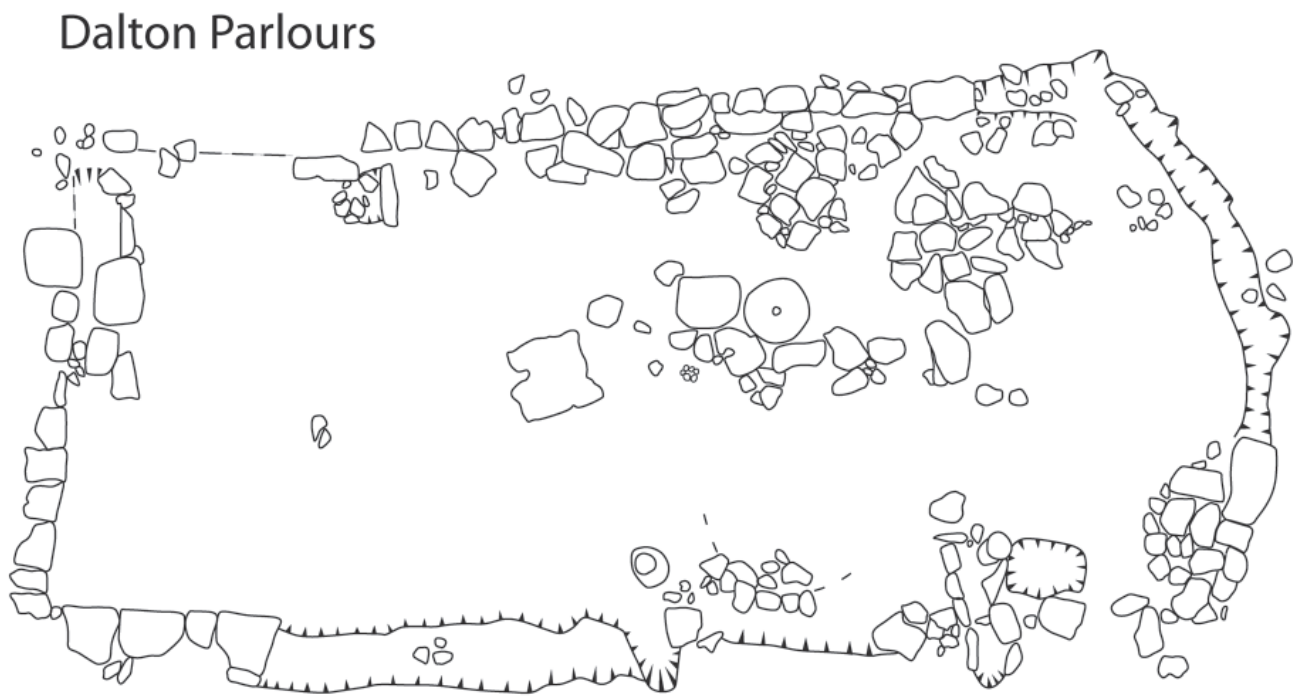

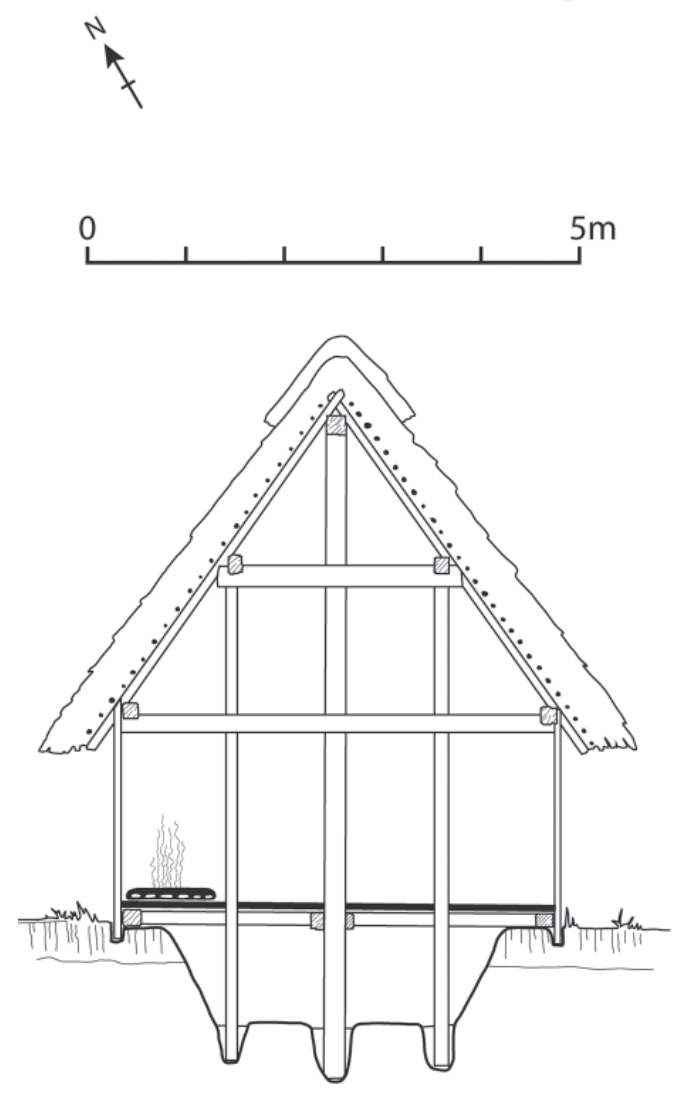

interpretation
A

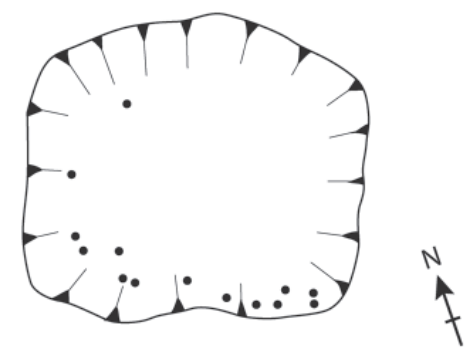

Appleby Magna

B

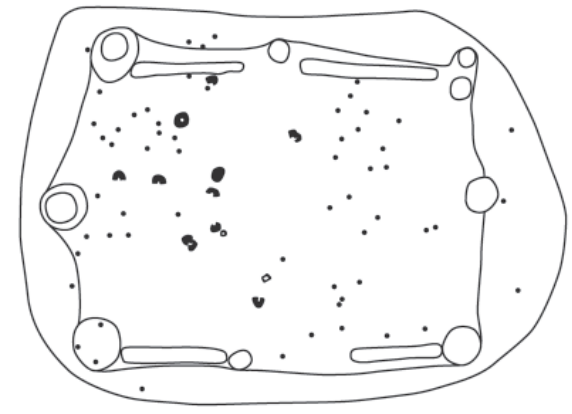

West Stow

Fig. 4. A. Roman sunken-featured buildings (after Clarke 2010 and Tindall 1990). B. Early medieval sunken-featured building from West Stow and its interpretation in section (after West 1985).

ton and Leicester itself ${ }^{37}$. The characteristic feature of all these Leicestershire examples and of a third- and fourthcentury sunken building at Dalton Parlours (West Yorkshire) is the clear association with crop-processing (Fig.

${ }^{37}$ Clarke 2010.
4A). Three of the four Appleby Magna buildings contained fragments of quern stones, and a possible threshing floor was found in one. There was a corn-drying kiln nearby. In the same way, the North Evington building was also found in association with a threshing floor and corndrying kiln. The Dalton Parlours building was interpreted 
by its excavators as a structure for crop-processing due to the presence of quern stones and a drying kiln ${ }^{38}$. The conclusion seems clear: these were all specialist Roman buildings associated with crop-processing and should be clearly distinguished from early medieval houses. The continental provenance of sunken-featured houses thus remains unchallenged.

Another aspect of the interpretation of sunken-featured buildings has also attracted controversy. The argument concerns whether the floor surface was set down in the depression below the level of the surrounding land, which is assumed to be the case on the continent of Europe, or whether the sunken area was covered by planks set at ground-level ${ }^{39}$. Initially, archaeologists favoured the idea of a pit-like building with a sloping roof rising from ground level, but the discovery of burnt planks which had fallen into the depression at West Stow suggested a new interpretation (Fig. 4B). The excavator suggested that these charred timbers were from the vertical walls of building and from a wooden floor set at ground level above the $\mathrm{pit}^{40}$. This interpretation provoked considerable controversy, but more recent research has turned in favour of the view that many, though not all SFBs had a groundlevel floor, rather than one at the base of the $\mathrm{pit}^{41}$.

The discovery of SFBs in the early medieval period in northern England and south-east Scotland has attracted considerable attention, since these were areas in which Germanic influence was thought to have been more limited. While SFBs might be expected in Yorkshire, where indeed many have been found ${ }^{42}$, their appearance further north in Northumberland at Milfield, New Bewick and Yeavering was less expected ${ }^{43}$. Subsequently, they have also been found at Dunbar, Hoddom, Ratho and Sprouston beyond the English border in southern Scotland ${ }^{44}$. While all these sites certainly have buildings which have pits set below ground level, it is very doubtful whether they are SFBs in the strict sense of that term. The buildings at Dunbar, Hoddom and Yeavering bear little resemblance to the two- or six-posthole structures which are so typical of Midlands and southern England ${ }^{45}$. Those at Milfield and

\footnotetext{
${ }^{38}$ Tindall 1990.

39 Tipper 2004 and for an alternative view, see Hamerow 2011, 146-51. Hamerow 2002, 31-35.

${ }^{40}$ West 1985, 119-21.

${ }^{41}$ Hamerow 1993, 14; Hamerow 2012, 59, 55; Tipper 2004, 184-85; Welch 1992, 21-25; West 2001, 71-75.

${ }^{42}$ Milne and Richards 1992; Powlesland 2000, 22-25; Wrathmell 2012, 115-18.

${ }^{43}$ Gates and O'Brien 1988; Hope-Taylor 1977, 88-91, 103-05.

${ }^{44}$ Lowe 2006, 54-56, 65-72; Perry 2000, 44-45; Smith 1991, 274-76; Smith $1995,104-11$
}

Sprouston are known only from aerial photographs, remain unexcavated and therefore of uncertain character. That leaves only the building at New Bewick which would not be out of place in a southern English context.

Just as the presence of SFBs on the England-Scots border has caused much speculation about their affinities, so too has the discovery of posthole buildings in that $\operatorname{area}^{46}$. Those deemed to be broadly similar to ones further south in England are usually labelled as 'Anglian', but this conceals as much as it reveals ${ }^{47}$. If the term 'Anglian' means anything, it seems to be used to refer to political control by the kingdom of Northumbria and with political control is assumed to come the methods of building associated with that kingdom. Yet, if the building style was derived from a Romano-British background, there is no reason necessarily to attribute its introduction to political events, but rather to the persistence of ideas of building and domestic space. A stage in the possible transition from a Romanized method of building to the timber structures of the early Middle Ages may be represented by buildings within the Roman fort of Birdoswald on Hadrian's Wall. Excavations showed that a late Roman stone granary which collapsed around $\mathrm{AD} 420$ was superseded by two phases of domestic timber buildings which may have stood until the early sixth century ${ }^{48}$. The relationship of these buildings to the houses of the early medieval tradition is discussed below.

There is a sharper contrast between the buildings of the Scottish borders and central belt of Scotland, and those of Angus and Perthshire. In the latter area they seem to have developed in the early Middle Ages from roundhouses to more rectangular buildings of so-called 'Pitcarmick type'. These buildings are named after the location where they were first identified in north Perthshire ${ }^{49}$. The buildings have round ends and curved sidewalls, often with a depression at one end which is thought to have been the position of the byre in which livestock was kept (Fig. 5B). The part of the building on the opposite side of the doorway was occupied by the owners of the animals ${ }^{50}$. Excavations at Pitcarmick North showed that the buildings were constructed of turf with stone revetting, and with stone footings at the gable end. The site produced radiocarbon dates from the hearth of 600-664 cal AD and 666-852 cal AD (at two sigma) ${ }^{51}$. A further building of the

\footnotetext{
${ }^{45}$ Tipper 2004, 68-70.

${ }^{46}$ Kirby 2011, 51-54; Perry 2000, 35ff.; Scull 1991, 54-57.

${ }^{47}$ Alcock 2003, 257.

48 Wilmott 2000, 13-14.

${ }^{49}$ For finds of this building type in Angus, see Turner 1998, 110.

${ }^{50}$ RCAHMS 1990, 12-13.
} 

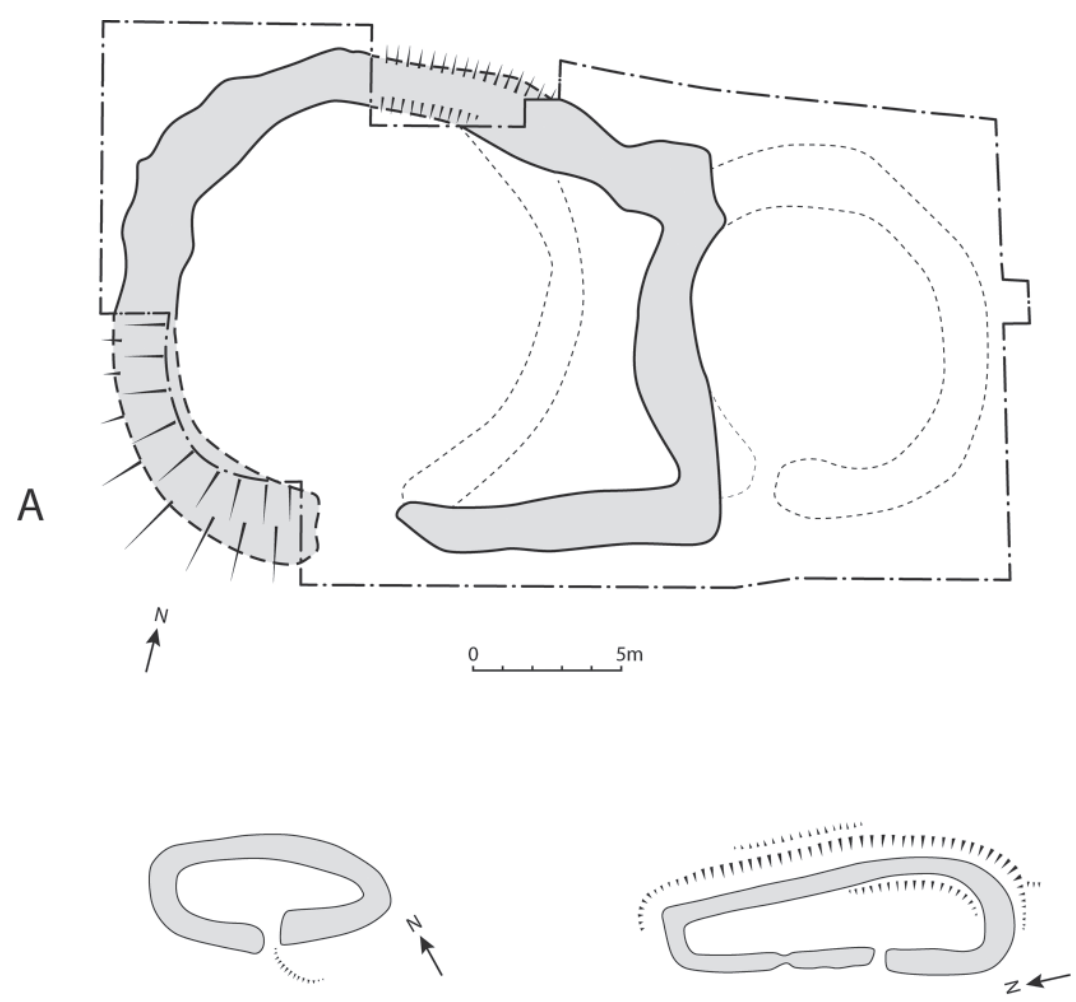

B

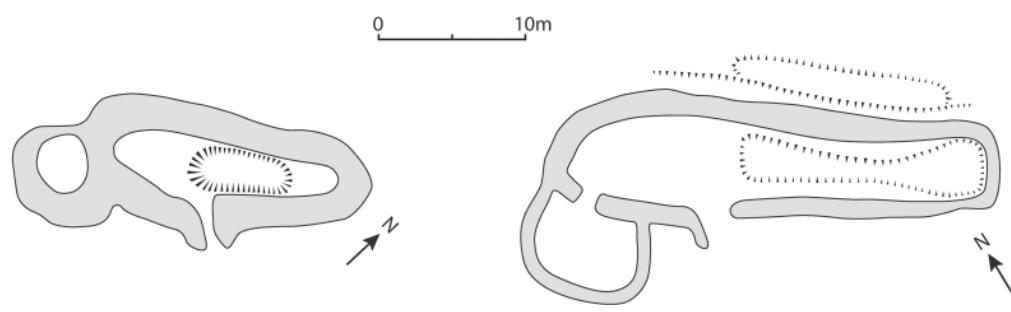

Fig. 5. A. An excavated building of Pitcarmick type from Carn Dubh overlying two earlier roundhouses (after Ridout 1995, 150). B. The earthworks of early medieval buildings at Pitcarmick (after RCAHMS 1990, 13). Note different scales.

same type was excavated at Carn Dubh near Pitlochry (Fig. $5 \mathrm{~A})$. The rather unusual shape was affected by the walls of the underlying roundhouse. It produced radiocarbon dates with a slightly wider bracket of $655-960 \mathrm{cal}$ AD (at two sigma $)^{52}$. These sites have established that the building type is broadly contemporary with the 'Anglian' buildings to the south.

The final cultural influence which we need to consider is of a rather different kind. It is suggested by the report of finds of roundhouses of early medieval date. In the first and second centuries roundhouses which had been the common form of dwelling before the advent of the Romans gradually disappeared, at least in southern and

${ }^{51}$ Barrett and Downes 1996 Batey 1993, 102-03; Batey 1994, 87-88. Full publication of this site in expected shortly.

${ }_{52}$ Rideout 1995, 153-55, 175. central England, though they survived longer in Wales, in Scotland as has already been noted, and also in northern England near the Scottish border. By the early Middle Ages the influence of Roman-style rectangular buildings was felt everywhere in Britain, except in the northern extremities. However, a recent excavation has raised the possibility that roundhouses might have been reintroduced into central England in the fifth or sixth centuries. Work at Quarrington (Lincolnshire) discovered three circular patterns of postholes with firm dating evidence ${ }^{53}$. The same excavation report drew attention to apparently similar structures found within the sixth- or seventh-century settlement at Thirlings. However, because the circular patterns of postholes at Thirlings are not discussed in that

${ }^{53}$ Taylor 2003, 237. The scale length on fig. 7 should clearly be $20 \mathrm{~m}$, not $10 \mathrm{~m}$ as shown. 
report, we do not know their date and cannot consider them further ${ }^{54}$. A rather different interpretation to that given by the excavators can be offered for the Quarrington structures. These posthole structures measure about $5 \mathrm{~m}$ in diameter, the same size as settings used for hay-ricks or corn-stacks. This seems a more likely use of these postsettings than to argue that roundhouses had been reintroduced in the early Middle Ages ${ }^{55}$.

This review of early medieval houses and their ethnic affinities has suggested that this question is rather more complex than has often been assumed. The movement from round to rectangular houses which occurred in Roman Britain represented a fundamental shift not only in the way that domestic space was structured, but also in the way in which people expressed themselves through their built environment ${ }^{56}$. Similarly, the alterations in building form from Romano-British types to those of the early medieval period will have been significant. A change in building design was not like adopting a new style of pottery but, it has been argued, was an expression of an entirely different perspective on the world. "It should be apparent to the archaeologist that the structuring of space incorporates cosmological and symbolic principles in many situations», Parker Pearson and Richards have argued. They warn, however, that the detection of these principles is often very difficult ${ }^{57}$. We cannot doubt, then, that the exact form of buildings was of crucial importance in the expression of ethnic identity, even though at present we have problems in understanding the meanings implicit in buildings.

What has intrigued archaeologists is both the similarities and differences between English houses and those on the other side of the North Sea. There were similarities in form as we have noted, but also very significant differences in terms of the uses to which the buildings were put. The absence in England of longhouses of continental type occupied by both humans and livestock is of particular note. It should remind us that migration involves not merely the introduction of aspects of the culture of the migrants, but also their acculturation. Ideas pass in more than one directions. The arguments for acculturation have been embraced more thoroughly nearer the Scottish border where it has long been argued that royal palace site of Yeavering represents a fusion of Anglian (that is Germanic) and native (that is British) influences. The problems

\footnotetext{
${ }^{54}$ O’Brien and Miket 1991, fig. 2.

${ }^{55}$ Gardiner forthcoming b.

56 Parker Pearson and Richards 1994a, 2-4.

${ }^{57}$ Parker Pearson and Richards 1994b, 38.
}

surrounding this interpretation have been extensively discussed $^{58}$. Yet, if we are going to follow this line of discussion, we are thrown back to questions of building structure. It is hardly possible to make progress in identifying the ethnic affinities of houses until architectural types can be more precisely defined.

\section{AN EARLY MEDIEVAL BUILDING TRADITION REDEFINED}

Few syntheses of early medieval houses in Britain from the fifth to the tenth century have been published, and few of these attempt to analyse rather than merely describe the buildings ${ }^{59}$. The only attempt to characterize English early medieval buildings in purely structural terms is a study by Simon James et al. which compared the buildings at Cowdery's Down to others of the sixth to eighth century and identified common features, some relating to the organization of the settlements, but the remainder concerned the plan and structure of individual buildings $s^{60}$. Their suggestion of cruck construction based on very slight evidence was dismissed in a subsequent paper by Alcock and Walsh, and that aspect is not considered further here ${ }^{61}$. The other features they identified may be summarized as follows:

i) use of a double-square plan (twice as long as wide)

ii) position of doorway in the middle of the long wall

iii) end walls generally less substantial than the side walls

iv) closely spaced uprights set in continuous trenches or individual postholes

While James et al.'s analysis was only applied to buildings before $\mathrm{AD} 800$, the characteristics of insubstantial end walls (feature iii) and closely spaced timber posts (feature iv) can be found in houses as late as the eleventh and twelfth century (see, for example, Fig 6D). Indeed, it is striking that some of the plans of the buildings recorded at Mucking and dating to the sixth or seventh centuries are fundamentally similar to those more than five hundred years later. This raises the possibility that it might be possible to identify a number of features which character-

\footnotetext{
${ }^{58}$ For a summary, see Driscoll 2005, 163-66.

${ }^{59}$ Notable overviews are Addyman 1972 and Rahtz 1976. More recent analyses are given by Hamerow $(2011 ; 2012)$.

${ }^{60}$ James et al. 1984.

${ }^{61}$ Alcock and Walsh 1993.
} 

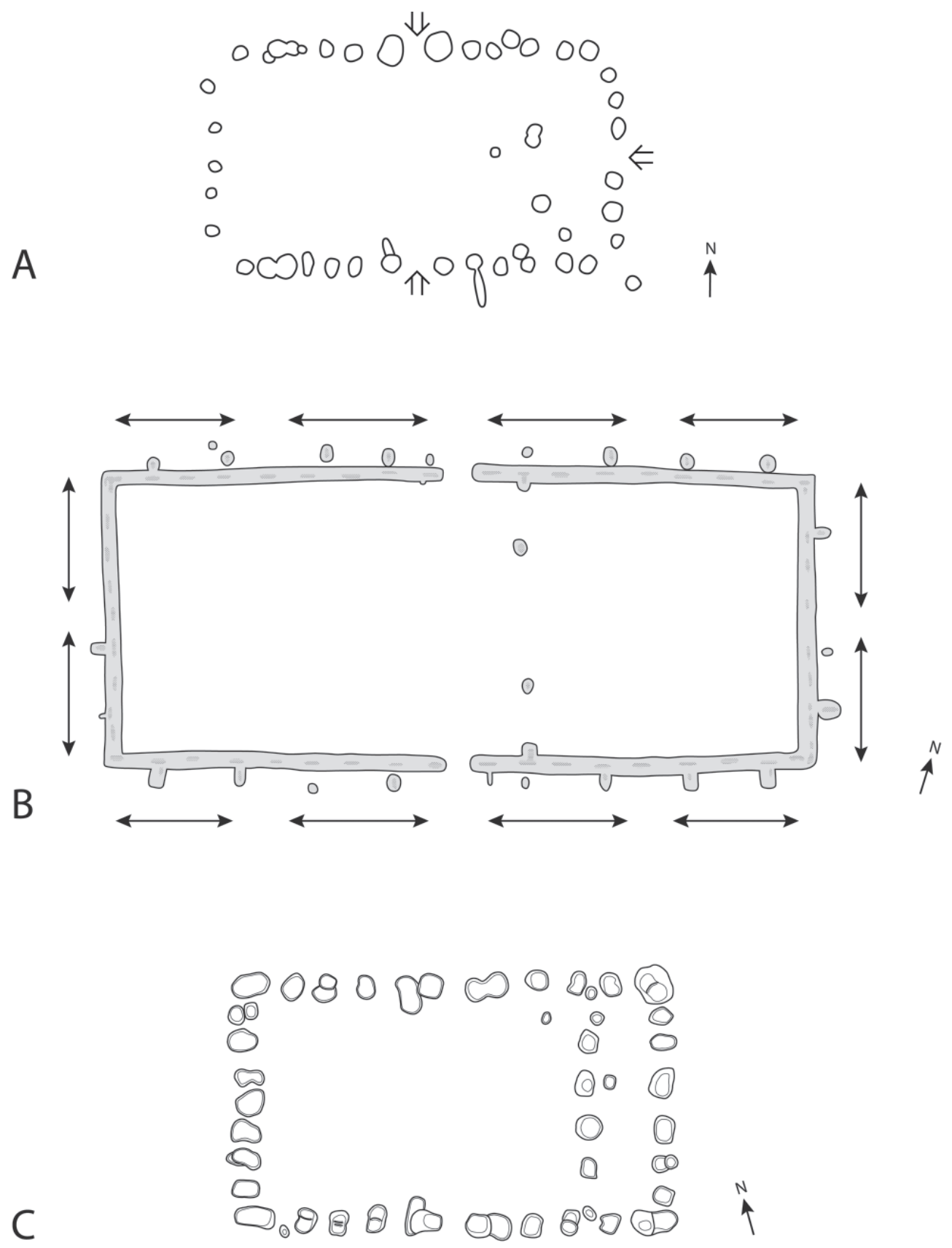

$0, \quad, \quad, \quad 5 \mathrm{~m}$

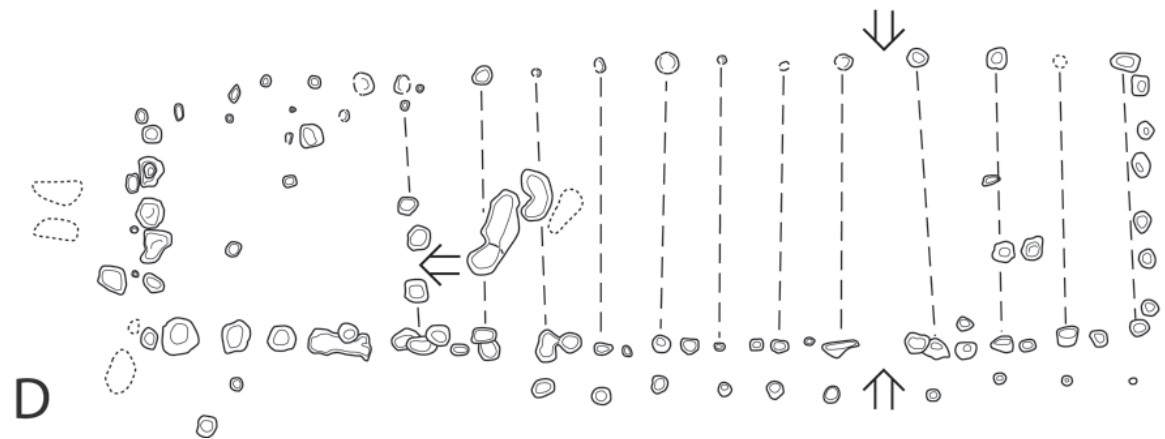

Fig. 6. Buildings of the early medieval tradition: A. Mucking PHB 3 (after Hamerow 1993), B. Cowdery's Down C14 (after Millett and James 1983), C. Chalton A20 (after Addyman and Leigh 1973), D. Springfield Lyons 3 (after Tyler and Major 2005). The pairing of posts is shown at Springfield Lyons where evidence for intermediate nonweight-bearing studs survived on the south side, but not on the north where they had been removed by ploughing. Beyond the posts on the south side were a number of supporting posts to prop up the building as the wall-posts decayed. 
ize a long-running early medieval tradition of construction.

We may begin with the characteristics identified and listed above in the seventh- to eighth-century buildings at Chalton. The first of these is the pairing of posts across the width of the building. This is a persistent feature of buildings from those at Mucking (Fig. 6A) until at least the eleventh century when it occurs, for example, in Building 3 at Springfield Lyons (Fig. 6D). It is not always possible to be certain that there are paired posts, particularly where the archaeological evidence is inadequate, but wherever there is clarity, equal number of posts are found on both of the long sides of the building. There is no aesthetic reason why buildings should have this feature, since the two sides could not have been viewed at the same time; the purpose is likely therefore to be structural. It seems probable that the pairs of posts were linked with a tie beam. We may guess that the reason for these numerous ties was to take the outward thrust of the rafters: each beam was associated with a pair of rafters. This interpretation suggests that the roofs of these early medieval buildings were similar to the common-rafter roofs recorded in the earliest surviving timber buildings. Moreover, the design of the roof with a beam and rafter couple would have been similar to the earliest known roof structure in Britain from Odda's Chapel at Deerhurst. This building was consecrated in 1056 and, although the roof timbers were removed and destroyed in 1965 in the belief that they were comparatively modern, it is probable that what survived until that time was part of the original roof. Photographs and an outline of the roof preserved in plaster on the end wall shows that it had a king post and raking struts. The tie beams set at intervals of about $0.67 \mathrm{~m}$ had halved joints to take the rafters ${ }^{62}$. Although this roof was on a masonry building and comes at the end of the period considered, it is possible that the excavated timber houses had somewhat similar structures.

The second feature identified in the Chalton excavations was the lack of emphasis on the corner posts and the presence of insubstantial end walls. The 'weak' corners, as they are sometime described, are also found over a long period of time and recur in so many buildings that they must be a product of the way in which houses were constructed. They can be seen in the buildings already mentioned at Mucking and Springfield Lyons, amongst many others of early medieval date. It is sometimes possible to demonstrate that there were two posts at the

${ }^{62}$ Currie $1983,58-60$ corner, as for example in Buildings A and B at Thirlings where clear post-ghosts were recorded or Building $\mathrm{P}$ at Cheddar where the positions of posts were detected by the depressions at the base of the post trench ${ }^{63}$. Only J. T. Smith has attempted to explain this feature in structural terms. He observed that at Cheddar the side and end walls appeared to be independent of each other ${ }^{64}$. This typically insightful comment must surely be correct. The side and end walls butted up against each other, perhaps just pegged together, or even standing a short distance apart. They must have been assembled and erected separately. The end walls were unnecessary for structural purposes as all the weight of the roof was carried on the side walls. Of course, walls at the end of the building were required for functional purposes, to keep the weather out. The end walls in some buildings were so light and insubstantial that no evidence has survived in the ground.

We can now turn to the third aspect of buildings noted first at Chalton - the careful alignment of the wall timbers. This feature is not evident in all buildings and, indeed it is clear that some buildings certainly did not have straight-sided walls. Archaeologists have devoted an immense effort to understand how it was possible to construct houses with posts which did not form straight lines ${ }^{65}$ Such ingenuity is unnecessary. It is clear from finds of timbers in London and Kingston-on-Thames from the end of the early medieval period that the tops of timber posts were joined by a wallplate, so they must have been tolerably well aligned ${ }^{66}$. The supposed 'poor alignment' sometimes identified by archaeologists can be explained as short lengths with numerous separate straight alignments. This may be seen with reasonable clarity in Structure C14 at Cowdery's Down (Fig. 6B). The building was supported on a series of plank-like posts placed towards the middle of the trench. The timbers in the trenches either side of the doorways both have two slightly different alignments. This is particularly marked in the eastern half of the building where, in both the north and south walls, there are changes in the direction, not only of the alignment of the timbers, but of the foundation trench itself. Whether this was an error in setting-out the building or was intentional is not clear. However, the structural consequences are important. It implies that the walls were divided into a series of lengths, each between $4 \mathrm{~m}$ and $5 \mathrm{~m}$ long. It is possible that the foundation trench was excavated and then the section

\footnotetext{
${ }^{63}$ O’Brien and Miket 1991, 63, 64; Rathz 1979, 111-14.

${ }^{64}$ Smith in Rathz 1979, 114.

${ }^{65}$ Beresford 1981; Dixon 2002, 94-95.
} 
of wall erected before digging the next length of trench. Evidence for this method of building is found in many other buildings where sections of wall trenches sometimes overlap or fall short of the adjoining lengths. An example of both such relationships can be seen in Building P at Cheddar and in Building S11 at Portchester ${ }^{67}$.

The changes in alignment at Cowdery's Down were quite subtle, but in other buildings they are much more marked. Such structures which are wider in the middle than at the ends have sometimes been called 'boat-shaped buildings' and compared with examples from the Viking areas of Europe and Scandinavia ${ }^{68}$. This is a misnomer because no buildings in England had curved walls. The walls, like those at Cowdery's Down are made up of a series of straight lengths set on different alignments. A further clear example can be found in the Long Hall at Cheddar where there is a marked change in alignments of both side walls at both ends ${ }^{69}$. It has been argued that this was not the results of imprecision is setting out buildings, but a deliberate device to create a false perspective and to make the buildings appear larger and more impressive than they were $^{70}$. Whatever the intention, the conclusion is clear: buildings were not constructed with poorly aligned posts. The post were always well positioned, but the walls were not necessarily in straight-sided.

The various features of the early medieval building tradition suggest a distinct form of the construction (Fig. 7). The walls were evidently constructed in lengths about $4 \mathrm{~m}$ or so long, each with a separate wall plate. These lengths of wall may be described as wall panels since they were effective erected and assembled individually. It is now clear that the end walls, where they were more substantial, were nothing more or less than separate wall panels. The walls were constructed in this modular fashion and then the separate elements were tied together by numerous beams set across the structure. The remarkable thing is that this method of construction seems to have persisted from the fifth until the twelfth century since the distinguishing archaeological traces are found throughout this period.

The essential features of the medieval building tradition may now be defined. We can begin with the four elements identified by James et al., though we need to add some qualification, shown here in brackets, to allow that changes took place in the period after that considered by

\footnotetext{
${ }^{66}$ Andrews et al. 2003, 14-15; Hill and Woodger 1999, 31-35.

${ }^{67}$ Cunliffe 1975, 30; Rahtz 1979, 112.

${ }^{68}$ Komber 2002.

${ }^{69}$ Rahtz 1979, fig. 31.

${ }^{70}$ Gardiner forthcoming a.
}

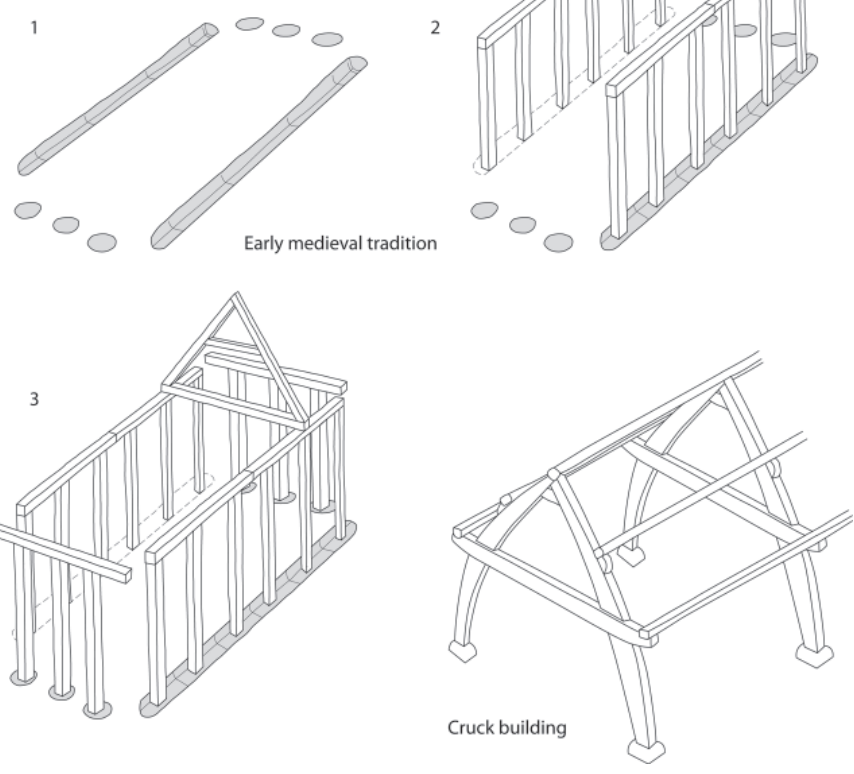

Fig. 7. The method of construction used in the early medieval tradition identifed here may be contrasted with cruck construction which though suggested by a number of archaeologists is not attested before the thirteenth century.

them:

i) use of a double-square plan (although this becomes much less common after the eighth century)

ii) position of doorway in the middle of the long wall (though there is more variation by the ninth and tenth centuries)

iii) end walls are (generally) less substantial than the side walls; the weight of the roof was overwhelmingly taken on the side walls

iv) closely spaced uprights set in continuous trenches or individual postholes (but the distance between posts increases later and non-weight-bearing posts or studs are found between the posts (Fig. 6D)).

To these features we can add:

v) posts were paired across the width of the building

vi) the wall posts were well aligned, though often in short lengths, and the heads of the posts were joined by wall plates.

\section{DISCUSSION}

The characteristics defined above, which are based on aspects of both plan and structure, allow us now to distinguish those regions with a common building tradi- 


\section{Birdoswald}

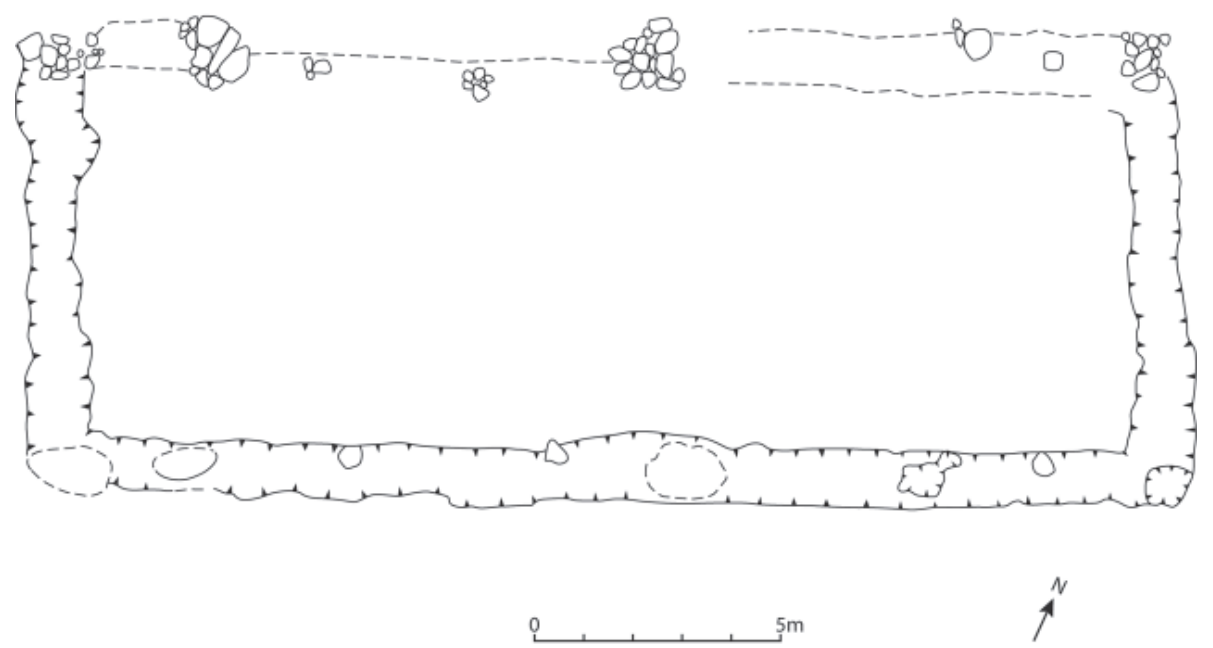

Lockerbie

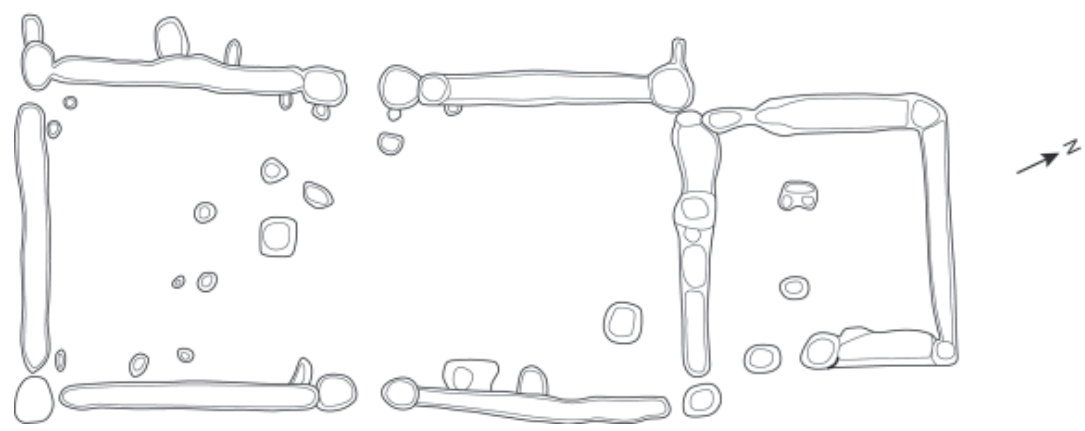

Fig. 8. Buildings of the Scottish border: the fifth-century timber hall at Birdoswald (after Wilmott 2000) and the 'Anglian' hall at Lockerbie (after Kirby 2011) dating to the second half of the fifth to first half of the seventh century.

tion. The task of identifying the roots from which this tradition sprang, whether continental or insular, must remain for the future. It is too large an issue to be tackled here, though it is possible to say something about the late Roman precedents. We can also consider the northern limits of the building tradition within Britain.

Late Roman and sub-Roman buildings in Britain not built of masonry were timber-framed structures constructed using wooden sills set on or above ground level ${ }^{71}$. This style persisted in buildings constructed after the $\mathrm{AD} 410$, the traditional date for the end of Roman settlement of Britain, for example in the town of Wroxeter and in the northern fort of Birdoswald. The first wooden building constructed in $c .420$ at the latter site appears to have been timber-framed with posts set in shallow postholes or slight depressions. The second phase dating to some fifty years later must also have been framed with the posts set on

\footnotetext{
${ }^{71}$ In addition to the examples cited below, see also Cunliffe 1977, 64-65.
}

post-pads, some set in a shallow trench (Fig. 8). The posts were set at greater intervals than buildings of the early medieval tradition and were not dependent upon being set in the ground to give the structure rigidity ${ }^{72}$. Everything points to these buildings belonging to the end of the Roman tradition, rather than to the early medieval patterns of construction in which ground-fast timbers were almost invariably used. ${ }^{73}$ Timber-framing requires that the building has strong, tightly fitting joints which allows the structure to stand up without the support of posts set in the ground. This form of construction disappeared around the end of the Roman era and was not used again until the thirteenth century.

The fairly sharp distinction between the Romanized methods of construction and those used in the early Middle Ages reflects the wider break in material culture in Britain in the fifth century. The sources of the early

\footnotetext{
${ }^{72}$ Goodburn 1991, 196-200; Wilmott 2000, 14.
} 
medieval methods of construction cannot be investigated here. Instead, it is appropriate to consider the area in which this developing tradition became established. We have already seen that the Highlands of Scotland lie beyond this style of building. The houses of Pitcarmick type were thoroughly different, not only in their use of earth and stone in the walling, but also in the accommodation of livestock and humans under the same roof. The situation is less certain in southern Scotland. The excavation at Dunbar produced only partial building plans which are very difficult to interpret. They do not immediately appear to have the distinctive features of the early medieval tradition identified above, nor do the better preserved buildings dating from the seventh to tenth century at Hoddom. However, the hall at Lockerbie dating from some point between second half of the fifth to first half of the seventh century is an entirely convincing example of a building in the early medieval tradition (Fig. 8). The main body of the building has a plan which is approximately twice as long as it is broad. The doorway is set centrally. The end wall trenches are set slightly beyond and do not extend up to the side walls. Even the square annex at the north end finds parallels with buildings further south. Only the deep post-settings at the corners are slightly unusual $7^{74}$.

\section{CONCLUSIONS}

Early medieval houses have largely disappeared as a particularly pressing problem for archaeological research in England. Enough examples have now been excavated that their general form is established and there seem to be few important research issues. This is illusory. In fact, our knowledge of houses of this period is extraordinarily poor. As we have shown, understanding of the structure of buildings is still at a basic level, and there are many aspects of houses about which even less is known. For example, we understand almost nothing about the internal arrangement of space within early medieval houses because few internal features survive to be excavated. It is often difficult even to establish the position of the hearth. Yet, poor as knowledge is for English early medieval houses, it is still infinitely better than the understanding of Scottish buildings, where so few structures have been found, or Wales where almost no examples are known. In those areas, there is a wider appreciation of the poverty of our knowledge.

One of the key issues which has emerged from this

\footnotetext{
${ }^{73}$ For the small number of buildings which did not use earth-fast timbers, see Gardiner 2004.

${ }^{74}$ Kirby 2011, 43-54.
}

survey of work on early medieval buildings in Britain has been the identification of a distinctive tradition of construction. This raises the question of the origins of this form of building and the way in which it spread across the greater part of Britain. Part of this question must be the reasons why Roman forms of construction disappeared. Roman methods persisted, in at least some places, into the fifth century but vanished shortly after. Whatever the reason for the introduction of buildings of the early medieval tradition, the form of construction was evidently successful and was used in buildings for at least five hundred years.

This paper has devoted little space to the later development of the early medieval tradition. It would be wrong to imagine that the form of houses stayed the same over a period of centuries. Whereas other archaeologists have tended to emphasise change, the present paper has laid stress on the continuities. Hamerow has shown that plan forms did alter throughout this period ${ }^{75}$. English buildings have often been studied either from the fifth to the seventh century or from the tenth century onwards. (There are relatively few excavated eighth- and ninthcentury houses.) This approach has tended to obscure the continuities which run over the longer period. Now we have established these, it may be possible to appreciate better the changes which took place within the overall framework of the building tradition.

\section{Acknowledgements}

I am grateful to Libby Mulqueeny who worked so hard to prepare the drawings and to Dr Piers Dixon for his comments on Scottish early medieval buildings.

\section{References}

Addyman, P. V. 1972. The Anglo-Saxon house: a new review, Anglo-Saxon England 1, 273-307.

Addyman, P. V. 1979. Vernacular buildings below ground, Archaeological Journal $136,69-75$.

Addyman, P. V. 1981. Cruck buildings: the evidence from excavations, in N. W. Alcock (ed.), Cruck Construction: An Introduction and Catalogue (CBA research report 42), 37-39. London: Council for British Archaeology.

Addyman, P. V. and Hall, R. A. 1991. Urban Structures and Defences (The Archaeology of York 8/3). London: Council for British Archaeology.

Addyman, P. V. and Leigh, D. 1973. The Anglo-Saxon village at Chalton, Hampshire: second interim report, Medieval Archaeology 17, 1-25.

Addyman, P. V., Leigh, D. and Hughes, M. J. 1972. Anglo-Saxon houses at Chalton, Hampshire, Medieval Archaeology 16, 13-31.

Alcock, L. 2003. Kings and Warriors, Craftsmen and Priests in Northern Britain $A D$ 550-850. Edinburgh: Society of Antiquaries of Scotland.

Alcock, N. W. and Walsh, D. 1993. Architecture at Cowdery's Down: a reconsideration, Archaeological Journal 150, 403-09.

Andrews, P., Lowe, J., Nichols, K., Phillpotts, C. and Powell, A. 2003. Charter Quay - The Spirit of Change: The Archaeology of Kingston's Riverside. Salisbury:

${ }^{75}$ Hamerow 2011, 130. 
Wessex Archaeology.

Barrett, J. C., and Downes, J. M., 1996. North Pitcarmick: a Radiocarbon Dated Chronology. Interim Report. Sheffield: University of Sheffield.

Batey, C. E. 1993. Discovery and Excavation in Scotland 1993. Edinburgh: Council for Scottish Archaeology.

Batey, C. E. 1994. Discovery and Excavation in Scotland 1994. Edinburgh: Council for Scottish Archaeology.

Bennett, P. Clark, P., Hicks, A., Rady, J. and Riddler, I. 2008. At the Great Crossroads: Prehistoric, Roman and Medieval Discoveries on the Isle of Thanet 1994-1995. Canterbury: Canterbury Archaeological Trust.

Beresford, G. 1981. The timber-laced wall in England, in A. Detsicas (ed.), Collectanea Historica: Essays in Memory of Stuart Rigold, 212-18. Maidstone: Kent Archaeological Society.

Chapman, J. and Hamerow, H. (eds) 1997. Migrations and Invasions in Archaeological Explanation (BAR international series 664). Oxford: Archaeopress.

Charles, F. W. B. 1981. Post-construction and the rafter roof: possible sources of some early structural elements of the timber-frame tradition, Vernacular Architecture 12, 3-19.

Clarke, S. 2010. Sunken-featured buildings on a late Romano-British farmstead, Rectory Lane, Appleby Magna, Leicestershire, Transactions of the Leicestershire Archaeological and Historical Society 84, 213-22.

Corser, P. 1993. Pre-Improvement settlement and cultivation remains in eastern Scotland, in R. Hingley (ed.), Medieval or later Rural Settlement in Scotland: Management and Preservation, 15-23. Edinburgh: Historic Scotland.

Cunliffe, B. W. 1976. Excavations at Portchester Castle. Volume II: Saxon London: Society of Antiquaries.

Cunliffe, B. W. 1977. The Romano-British village at Chalton, Hants, Proceedings of the Hampshire Field Club and Archaeological Society 33, 45-67.

Currie, C. R. J. 1983. A Romanesque roof at Odda's chapel, Deerhurst, Gloucestershire?, Antiquaries Journal 63, 58-63.

Dixon, P. 1982. How Saxon is the Saxon house?, in P. J. Drury (ed.), Structural Reconstruction: Approaches to the Interpretation of the Excavated Remains of Buildings (BAR British series 110), 275-87. Oxford: British Archaeological Reports.

Dixon, P. 2002. The reconstruction of the buildings, in S. Losco-Bradley, and G. Kinsley, Catholme: An Anglo-Saxon Settlement on the Trent Gravels in Staffordshire, 89-99. Nottingham: Dept of Archaeology, University of Nottingham.

Driscoll, S. T. 2005. Ad Gefrin and Scotland: implications of the Yeavering excavations for the North, in P. Frodsham and C. O'Brien (eds), Yeavering: People, Power and Place, 161-73. Stroud : Tempus.

Drury, P. J. and Wickenden, N. P. 1982. An early Saxon settlement within the Romano-British small town at Heybridge, Essex, Medieval Archaeology 26, 140.

Fowler, P. J. 1999. Bede's World, UK: the monk who made history, in P. G. Stone and P. G. Planel (eds), The Constructed Past: Experimental Archaeology, Education and the Public, 245-57. London: Routledge.

Gardiner, M. F. 2004. Timber buildings without earth-fast footings in VikingAge Britain, in J. Hines, A. Lane and M. Redknap (eds), Land, Sea, and Home: Proceedings of a Conference on Viking Age Settlement in the British Isles, 345-58, London: Society for Medieval Archaeology.

Gardiner, M. F. 2011. Late Saxon settlement, in H. Hamerow, S. Crawford, D. Hinton (eds), A Handbook of Anglo-Saxon Archaeology, 198-217. Oxford: Oxford University Press.

Gardiner, M. F. forthcoming a. The sophistication of Late Anglo-Saxon timber buildings, in M. G. Shapland and M. D. Bintley (eds), Timber, Trees and Woodland in Anglo-Saxon England. Oxford: Oxford University Press.

Gardiner, M. F. forthcoming b. Stacks, barns and granaries in Early and High Medieval England: crop storage and its social and economic implications, in J. A. Quirós Castillo (ed.), Horrea, Silos and Barns. Vitoria-Gasteiz: University of the Basque Country.

Gates, T. and O'Brien, C. 1988. Cropmarks at Milfield and New Bewick and the recognition of Grubenhäuser in Northumberland, Archaeologia Aeliana fifth series, 16, 1-9.

Goodburn, D. 1991. A Roman timber framed building tradition, Archaeological Journal 148, 182-204.
Goodburn, D. 1992. Woods and woodland: carpenters and carpentry, in G. Milne, Timber Building Techniques in London c. 900-1400, 106-30. London: London and Middlesex Archaeological Society.

Goodburn, D. 2000. Wooden remains as an archaeological resource: some insights from the London 'wetlands', Archaeology in the Severn Estuary 11, $187-95$.

Goodburn, D. 2007. The eleventh- and twelfth-century timber buildings, in D. Bowsher, T. Dyson, N. Holder and I. Howell (eds), The London Guildhall: An Archaeological History of a Neighbourhood from Early Medieval to Modern Times, 307-19. London: Museum of London Archaeological Service.

Grocock, C. 2010. Barriers to knowledge: coppicing and landscape usage in the Anglo-Saxon economy, in N. J. Higham and M. J. Ryan (eds), The Landscape Archaeology of Anglo-Saxon England, 23-37. Woodbridge: Boydell Press.

Hall, R. A. and Hunter-Mann, K. 2002. Medieval Urbanism in Coppergate: Refining a Townscape. York: Council for British Archaeology.

Hamerow, H. 1993. Excavations at Mucking. Volume 2: The Anglo-Saxon Settlement. London: English Heritage.

Hamerow, H. 1994. Migration theory and the Migration Period, in B. Vyner (ed.), Building on the Past: Papers Celebrating 150 years of the Royal Archaeological Institute, 164-77. London: Royal Archaeological Institute.

Hamerow, H. 1999. Anglo-Saxon timber buildings: the continental connection, in H. Sarfatij, W. H. Verwers and P. J. Woltering (eds), In Discussion with the Past. Archaeological Studies Presented to W. A. van Es, 119-128. Amersfoort: Rijksdienst voor het Oudheidkundig Bodemonderzoek.

Hamerow, H. 2002. Early Medieval Settlements: The Archaeology of Rural Communities in Northwest Europe 400-900. Oxford: Oxford University Press.

Hamerow, H. 2011. Timber buildings and their social context, in H. Hamerow, S. Crawford, D. Hinton (eds), A Handbook of Anglo-Saxon Archaeology, 12855. Oxford: Oxford University Press.

Hamerow, H. 2012. Rural Settlements and Society in Anglo-Saxon England. Oxford: Oxford University Press.

Hardy, A., Watts, M. and Goodburn, D. 2011. The mid-Saxon mill at Northfleet, in P. Andrews, E. Biddulph, A. Hardy and R. Brown, Settling the Ebbsfleet Valley. High Speed I Excavations at Springhead and Northfleet, Kent. Volume 1: The Sites, 307-49. Oxford and Salisbury: Oxford Wessex Archaeology.

Härke, H. 1998. Archaeologists and migrations: a problem of attitude?, Current Anthropology 39, 19-45.

Hill, J. and Woodger, A. 1999. Excavations at 72-75 Cheapside/83-93 Queen Street, City of London. London: Museum of London.

Hoffsummer, P. 2009. A typology of roof frames, in P. Hoffsummer (ed.), Roof Frames from the Eleventh to the Nineteenth Century: Typology and Development in Northern France and in Belgium, 162-257. Turnhout: Brepols. (Originally published in P. Hoffsummer. 2002. Les Charpentes du Xe au XIXe Siècles. Typologie et Évolution en France du Nord et en Belgique. Paris: MONUM.)

Hope-Taylor, B. 1977. Yeavering: An Anglo-British Centre of Early Northumbria. London: Her Majesty's Stationery Office.

James, S., Marshall, A. and Millett, M. 1984. An early medieval building tradition, Archaeological Journal 141, 182-215.

Kirby, M. 2011. Lockerbie Academy: Neolithic and Early Historic Timber Halls, a Bronze Age Cemetery, an Undated Enclosure and a Post-Medieval Corn-Drying Kiln in South-West Scotland (http://www.sair.org.uk/sair46/).

Komber, J. 2002. Viking Age architecture in space and time, in J. Klápště (ed.), The Rural House from the Migration Period to the Oldest Still Standing Buildings: Ruralia IV, 13-29. Prague: Institute of Archaeology, Academy of Sciences of the Czech Republic.

Lowe, C. 2006. Excavations at Hoddom, Dumfriesshire: An Early Ecclesiastical Site in South-West Scotland. Edinburgh: Society of Antiquaries of Scotland.

Marsden, P. 1989. A late Saxon logboat from Clapton, London Borough of Hackney, International Journal of Nautical Archaeology and Underwater Exploration $18,89-111$.

Meeson, R. A. 2011. Medieval roofs in the West Midlands: the potential of archaeology and tree-ring dating, in J. Walker (ed.), The English Medieval Roof: Crownpost to Kingpost, 63-90. Chelmsford: Essex Historic Buildings Group.

Miles, D. 1986. Archaeology at Barton Court Farm, Abingdon, Oxon. London: Council for British Archaeology. 
Millett, M. and James, S. 1983. Excavations at Cowdery's Down, Basingstoke, Hampshire, 1978-8, Archaeological Journal 140, 151-279.

Mills, S. 1999. (Re)constructing Northumbrian timber buildings, in J. Hawkes and S. Mills (eds), Northumbria's Golden Age, 66-72. Stroud: Sutton Publishing.

Milne, G. 1992. Timber Building Techniques in London c.900-1400: An Archaeological Study of Waterfront Installations and Related Material. London: London and Middlesex Archaeological Society.

Milne, G. and Richards, J. D. 1992. Wharram. A Study of Settlement on the Yorkshire Wolds XIII. Two Anglo-Saxon Buildings and Associated Finds. York: Department of Archaeology, University of York.

O'Brien, C. and Miket, R. 1991. The early medieval settlement of Thirlings, Northumberland, Durham Archaeological Journal 7, 57-91.

Parker Pearson, M. and Richards, C. 1994a. Ordering the world: perceptions of architecture, space and time, in M Parker Pearson and C. Richards (eds), Architecture and Order: Approaches to Social Space, 1-37. London: Routledge.

Parker Pearson, M. and Richards, C. 1994b. Architecture and order: spatial representation and archaeology, in M Parker Pearson and C. Richards (eds), Architecture and Order: Approaches to Social Space, 38-72. London: Routledge.

Parsons, D. 1991. Stone, in J. Blair and N. Ramsey (eds), English Medieval Industries: Craftsmen, Techniques, Products, 1-27. London: Hambledon Press.

Perry, D. R. 2000. Castle Park, Dunbar: Two Thousand Years on a Fortified Headland. Edinburgh: Society of Antiquaries of Scotland.

Powlesland, D. 2000. West Heslerton settlement mobility: a case of static development, in H. Geake and J. Kenny (eds), Early Deira: Archaeological Studies of the East Riding in the Fourth to Ninth Centuries AD, 19-26. Oxford: Oxbow Books.

Rahtz, P. A. 1976. Buildings and rural settlements, in D.M. Wilson (ed.), The Archaeology of Anglo-Saxon England, 49-98. Cambridge: Cambridge University Press.

Rahtz, P. A. 1979. The Saxon and Medieval Palaces at Cheddar (BAR British ser. 65). Oxford: British Archaeological Reports.

Rahtz, P. A. and Meeson, R. A. 1992. An Anglo-Saxon Watermill at Tamworth: Excavations in the Bolebridge Street area of Tamworth, Staffordshire in 1971 and 1978. London; Council for British Archaeology.

Rahtz, P. A., Smith, J. T., Beresford, G and Barker, P. A. 1982. Architectural reconstruction of timbers buildings from archaeological evidence: comments on F.W.B. Charles's 'Post-construction and the rafter roof', Vernacular Architecture 13, 39-47.

RCAHMS (Royal Commission on the Ancient and Historical Monuments of Scotland). 1990. North-East Perth: An Archaeological Landscape. Edinburgh: Her Majesty's Stationery Office.

Reynolds, P. J. 1982. Substructure to superstructure, in P. J. Drury (ed.), Structural Reconstruction: Approaches to the Interpretation of the Excavated Remains of Buildings (BAR British series 110), 173-98. Oxford: British Archaeological Reports.

Reynolds, P. J. 1994. Experimental Archaeology : a Perspective for the Future (C. J. C. Reuvens lecture 5). Alphen aan den Rijn: Stichting voor de Nederlandse Archeologie.

Rideout, J. S. 1995. Carn Dubh, Moulin, Perthshire: survey and excavation of an archaeological landscape 1987-90, Proceedings of the Society of Antiquaries of Scotland 125, 139-95.

Rodwell, W. 1986. Anglo-Saxon church building: aspects of design and construction, in L. A. S. Butler and R. K. Morris (eds), The Anglo-Saxon Church: Papers on History, Architecture and Archaeology in Honour of Dr H. M. Taylor (CBA research report 60), 156-74. London: Council for British Archaeology.

Scull, C. 1991. Post-Roman phase I at Yeavering: a re-consideration, Medieval Archaeology 35, 51-63.
Shapland, M. G. forthcoming. Timber as the secular building material of AngloSaxon society, in M. G. Shapland and M. D. Bintley (eds), Timber, Trees and Woodland in Anglo-Saxon England. Oxford: Oxford University Press.

Smith, A. N. 1995. The excavation of Neolithic, Bronze Age and Early Historic features near Ratho, Edinburgh, Proceedings of the Society of Antiquaries of Scotland 125, 69-138.

Smith, I. M. 1991. Sprouston, Roxburghshire: an early Anglian centres of the eastern Tweed Basin, Proceedings of the Society of Antiquaries of Scotland 121, 261-94.

Smith, N. 2012. The Anglo-Saxon mystery of Prior's Hall, British Archaeology 125 (July/August 2012), 40-43.

Smith, J. T. 1958. Medieval roofs: a classification, Archaeological Journal 115, 111-49.

Taylor, G. 2003. An Early to Middle Saxon settlement at Quarrington, Lincolnshire, Antiquaries Journal 83, 231-80.

Tindall, A. 1990. The Roman structures, in S. Wrathmell and A. Nicholson (eds), Dalton Parlours: Iron Age Settlement and Roman Villa, 33-74. Wakefield: West Yorkshire Archaeological Service.

Tipper. J. 2004. The Grubenhaus in Anglo-Saxon England: An Analysis and Interpretation of the Evidence from a Most Distinctive Building Type. Yedingham: Landscape Research Centre.

Tipper. J. forthcoming. Experimental Archaeology and Fire: The Investigation of a Burnt Reconstruction at West Stow Anglo-Saxon Village. Ipswich: Suffolk County Council.

Turner, R. 1998. Discovery and Excavation in Scotland 1998. Edinburgh: Council for Scottish Archaeology.

Tyers, I., Groves, C., Hillam, C. and Boswijk, G. 1997. Tree-ring dates from Sheffield University, Vernacular Architecture 28, 138-58.

Tyler, S. and Major, H. 2005. The Early Anglo-Saxon Cemetery and Later Saxon Settlement at Springfield Lyons, Essex (East Anglian Archaeology 111). Chelmsford: Essex County Council.

Ulmscheider, K. 2011. Settlement hierarchy, in H. Hamerow, S. Crawford, D. Hinton (eds), A Handbook of Anglo-Saxon Archaeology, 156-71. Oxford: Oxford University Press.

Walker, J. 1999. Late-twelfth and early-thirteenth-century aisled buildings: a comparison, Vernacular Architecture 30, 21-53.

Walton, J. 1948. The development of the cruck framework, Antiquity 22, 17989.

Welch, M. G. 1992. Anglo-Saxon England. London: Batsford.

West, S. E. 1985. West Stow: The Anglo-Saxon Village. Volume 1: Text. Ipswich: Suffolk County Planning Department.

West, S. E. 2001. West Stow Revisited. Bury St Edmunds: West Stow Trust.

Wilmott, T. 2000. The late Roman transition at Birdoswald and on Hadrian's Wall, in T. Wilmott and P. Wilson (eds), The Late Roman Transition in the North: Papers from the Roman Archaeology Conference, Durham 1999 (BAR British series 299), 13-23. Oxford: Archaeopress.

Wrathmell, S. 2012. Wharram. A Study of Settlement on the Yorkshire Wolds XIII. A History of Wharram Percy and its Neighbours. York: Department of Archaeology, University of York.

Zimmermann, W. H. 1988. Regelhafte Innengliederung prähistorischer Langhäuser in den Nordseeanrainerstaaten, Germania 66, 465-89.

Zimmermann, W. H. 1999. Favourable conditions for cattle farming, one reason for the Anglo-Saxon migration over the North Sea? About the byre's evolution in the area south and east of the North Sea and England, in H. Sarfatij, W. H. Verwers and P. J. Woltering (eds), In Discussion with the Past. Archaeological Studies Presented to W. A. van Es, 129-144. Amersfoort: Rijksdienst voor het Oudheidkundig Bodemonderzoek.

Recibido: 3 de Julio de 2012 Aceptado: 17 de octubre de 2012 